\title{
The Role and Sustainability of Microfinance Banks in Reducing Poverty and Development of Entrepreneurship in Urban and Rural Areas in Nigeria
}

\author{
Abu Ikponmwosa Noruwa (Corresponding author) \\ Department of Finance \\ University of Lagos, Nigeria \\ E-mail: abuikponmwosa@yahoo.com \\ Ezike John Emeka \\ Department of Finance \\ University of Lagos, Nigeria \\ E-mail: john_ezike@yahoo.com
}

$\begin{array}{lc}\text { Received: January 5, } 2012 & \text { Accepted: March 1, } 2012 \quad \text { Published: May 15, } 2012 \\ \text { doi:10.5430/ijba.v3n3p33 } & \text { URL: http://dx.doi.org/10.5430/ijba.v3n3p33 }\end{array}$

\begin{abstract}
The achievement of good economic growth is anchored around an environment of well focused policies aimed at poverty eradication through the empowerment of the people by availing them of access to factors of production, particularly credit. The study examines the role of Micro-finance banks in reducing poverty and the development of entrepreneurship. Data were collected through structured questionnaires and administered to entrepreneurs (small scale enterprises) and micro-finance banks within the Lagos State area.

The study identified high rate of loan default among the SMEs, which poses serious consequences for microfinance banks. It was also established that the challenges facing microfinance banks include, among others, the documentation of credit process, wrong information, identity of the loan applicant, and unstable economic situation in the country.
\end{abstract}

Keywords: Entrepreneurship, Small and Medium Scale Enterprise (SME), Micro-finance Banks

\section{Introduction}

In Nigeria, credit has been recognized as an essential tool for entrepreneurship development. If the people of Nigeria have a limited capacity to invest in capital, productivity is restricted, incomes are inhibited, domestic savings remain low. A lack of access to financial institutions also hinders the ability for entrepreneurs in Nigeria to engage in new business ventures, inhibiting economic growth and often the sources and consequences of entrepreneurial activities are neither financially nor environmentally sustained. Microfinance banks serve as a means to empower the poor and provide valuable tool to assist the economic development process. About 70 percent of the population are engaged in the informal sector or in agricultural production. The Federal and state governments have recognized that for sustainable growth and development, the financial empowerment of the rural areas is vital, being the repository of the predominantly poor in society and in particular the SMEs. If this growth strategy is adopted and the latent entrepreneurial capabilities of this large segment of the people is sufficiently stimulated and sustained, then positive multipliers will be felt throughout the economy. To give effect to these aspirations various policies have been instituted over time by the Federal Government to improve rural enterprise production capabilities. (Olaitan, 200).

Imagine you are a poor woman in Ibadan. You work hard almost every day weaving mats. In five days you can finish a mat that sells for less than N200. When your children get sick, there is no money for medicine. How much would it change your life, if you could borrow $\$ 5000$ to buy a sewing machine.

The above example is real. Olowe Damilola was a poor mat weaver in Ibadan, who obtained $\$ 5000$ loan from the microfinance bank to buy a second-hand sewing machine, and started a small business making clothes, which her husband sells in the village market. Before her first loan, Olowe Damilola and her family frequently went hungry and never had money for family medical care. She could not afford even the very small education fees for the children. Now, 
the family eats three healthy meals, with a diet, including vegetables with a small amount of meat and fish. Her children attend good school, and she has some money saved for emergencies. This paper is aimed at examining the role played by microfinance banks towards reducing poverty and development of entrepreneurship in urban and rural areas of Nigeria. It will also identify the challenges facing the microfinance banks.

Data were collected through structured Questionnaires, administered to Small Scale Enterprises and Micro Finance Banks within the Lagos State. The collected data was analyzed using the simple content analysis.

To this end, the paper is organized into five parts, after the introduction, section II deals with literature review, covering conceptual and theoretical issues relating to entrepreneurship and microfinance as part two, part three contains the data and methodology, partly discusses results and analysis while the last part contains concluding remarks and recommendations..

\section{Literature Review}

It has been stated that robust economic growth cannot be achieved without putting in place a well focused policy to reduce poverty, through empowering the people, by increasing their access to factors of production, especially credit. The latent capacity of the poor for entrepreneurship would be significantly enhanced through the provision of microfinance services which would enable them engage in economic activities, and be more self reliant, thus increasing employment opportunities, enhancing household income and creating wealth $\mathrm{CBN}(2004)$

The experience of many countries indicate that entrepreneurship which manifest in the form of Small and Medium Scale Enterprises (SMEs) can meaningfully contribute to the attainment of country's economic development objectives. These objectives include output expansion, employment generation, location of industries among regions of a country, income redistribution, promotion of indigenous entrepreneurship and technology, as well as production of intermediate goods to strengthen, inter and intra industrial linkages. These among others, explain the increased interest, which many countries have shown in the promotion of entrepreneurship (Small Scale Enterprises) since the 1970s. Governments have therefore designed programmes of assistance to enhance the achievement of these objectives.

These are usually in the areas of Finance, Extension and Advisory Services, Training and the Provision of Infrastructural facilities. Financing programmes have attracted more attention than others, because every enterprise requires funds for its capitalization, working capital and rehabilitation needs, as well as the creation of new investments. The recent surge of interest in SMEs and entrepreneurship, probably owes more to a heightened awareness among policy makers and international agencies about the problems of unemployment and poverty, than any change of heart among economists or specialists in industrial development.

It is almost a truism that even with the right compliment of entrepreneurial motivations, starting a small business may be frustrated by lack of a core ingredient - capital. With a few exceptions, the initial financial investment into a small business venture, comes from its owner's personal wealth; sometimes supplemented by family members; friends and or other non-institutional sources. If this initial financial outlay serves the needs of the early stage of a small business enterprise (and it hardly does), sooner or later, needs change and even multiply, making it necessary for additional financial investment, from external sources. Okigbo (1981) summed up the finance problem of Nigeria's small business in these words. The question that is difficult to answer is whether the critical bottleneck in the small scale sector is finance for capital equipment or for working capital.

The availability and cost of finance are regarded among the factors militating against the growth of SMEs. Although access to finance does not by itself guarantee growth and sustenance of small business, it has been shown that absence of adequate level of finance can frustrate the formation or growth of SMEs. Historically, business as we know it today, is said to stem from the theory of LAISSEZ-FAIRE CAPITALISM as propounded by Adam Smith (1776) in his epochal work - "The Wealth of Nations".

According to Smith (1776), a society's economic needs are best served when the people are free to pursue their own self-economic interest. Under these conditions, every individual would obviously be working for the benefit of the society as a whole and at the same time meeting his own economic interest.

The theory also advocates for property ownership, economic freedom, competitive markets and limited role of government in business. On property ownership and economic freedom, Smith's argument was that the creation and distribution of wealth should be left in the hand of private individuals.

By implication, the resources for the creation of wealth or factors of production (land, labour and capital) should be privately owned by the citizens and not by government. There lies the emergence of entrepreneurs who own and manage small and medium scale enterprises. 


\subsection{Entrepreneurship}

An entrepreneur is a person of very high aptitude who pioneers change, organize production and takes the risks associated with the production process. An entrepreneur can also be viewed as a person that wants to work for himself; it is sometimes synonymous with self employment. Entrepreneurship therefore by implication is the act of being an entrepreneur, it involves all the activities and functions undertaken by an entrepreneur. Entrepreneurship is believed to provide an important avenue for individuals to advance up the income ladder. For some, it may provide a better route than paid employment, while for others, who may be disadvantaged when pursuing paid employment, it may provide the only route. Entrepreneurs are charged with the responsibility of innovating new products, better production method, creation of markets and managing the production process. They in a nutshell, engage in wealth creation. Financing therefore is needed by entrepreneurs to enable them carry out their functions effectively.

\subsection{Overview of Microfinance Banks in Nigeria}

Currently microfinance banks are of two forms, as all licensed community banks in Nigeria that met CBN guidelines have been transformed to Microfinance Banks. The two forms of Microfinance Banks (MFBs) are; (1) microfinance Banks (MFBs) licensed to operate as a unit. These are hitherto community banks licensed to operate branches andlor cash centres subject to meeting the prescribed prudential requirements and availability of free funds for opening branches $\backslash$ cash centres. The minimum paid-up capital for this category of banks is $\$ 20 \mathrm{~m}$ for each branch. The branching should be gradual within a local council before it spreads to other local councils and state (11) Micro-Financed Banks licensed to operate in a state. These are MFBs licensed to operate in all parts of the state at once without recourse to gradual coverage (spread) as in unit MFBs. The minimum paid up capital for this category of banks is $\$ 1$ billion. About 600 Community Banks have migrated to Microfinance Banks by January $1^{\text {st }}, 2008$ and there are several others that have been licensed to operate. (CBN, 2008)

\subsection{Role of Microfinance Banks in Reducing Poverty and Development of Entrepreneurship in Rural Areas}

\subsubsection{Credit Delivery}

This is perhaps one of the most important roles of microfinance banks as the loans extended are used to expand existing businesses and in some cases to start new ones. According to CBN (2008) microfinance loans granted to clients is increasing from 2007 to date and most of it goes to financing microenterprises in rural areas. Ketu, (2008) observed that microfinance banks have disbursed more than $\$ 800$ million micro credits to over 13,000 farmers across the country to empower their productive capacities. As such it is expected that agricultural output will increase with the increase in funding .The entrepreneurial capacity of the farmers will thus improve.

\subsubsection{Boosting Small Scale Enterprises/Agriculture}

About 60 percent of poor people in the country live in the rural areas, and 80 percent of them are farmers and artisans (NBS, 2005). Microfinance banks have therefore been the main sources of funding to these disadvantaged groups. Rural people are empowered through microfinance loans and services and hence small scale agricultural practice and microenterprise is developed. Governments go into co-operatives to partner with the microfinance banks to raise bulk loans to be disbursed to the beneficiaries in so doing the banks are increasing and sustaining the number of people going into small businesses.

\subsubsection{Employment Generation}

Agriculture and microenterprises contribute immensely to job creation, and are of particular interest to all Microfinance Banks in rural areas. Microfinance banks have so far engaged in extending credits and other services to many rural enterprises and hence generating employment and promoting entrepreneurship. The promotion of employment in rural areas by microfinance banks covers the following areas; blacksmithing, gold-smiting, watch repairing, bicycle repairing, basket weaving, barbing, palm wine tapping, cloth weaving, dyeing, food selling, carpentry, brick-laying, pot-making, leather works and drumming. Even though found in urban areas, these industries are more prominent in the rural areas. It has, therefore, been acknowledged that the rural setting is an arena of many industries, which could be developed to contribute significantly to the national economy, just as rural people are more frequently self-employed than urban people (Ketu, 2008).

\subsubsection{Improvement in Skill Acquisition}

Improvement of the condition of women through the provision of, skills acquisition and adult literacy is another role played by microfinance banks. This is done through building capacities for wealth creation among enterprising poor people and promoting sustainable livelihood by strengthening rural responsive banking methodology and the introduction of simple cost-benefit analysis in the conduct of businesses. In most cases a profit sharing agreement is 
entered between a bank and an entrepreneur and new methods and innovations are passed to the prospective entrepreneur by the banks professionals, while at the end of the production period the proceeds are shared and the entrepreneur, if he so wishes, can continue on his own after the necessary skills and production techniques are acquired. (Umar, 2008).

\subsubsection{Facilitates Poverty Alleviation}

Employment and income generation are important aspects of poverty alleviation efforts. Microfinance banks have accelerated the operation of government poverty alleviation programmes and in doing that promising entrepreneurs are supported and new ones emerged. The federal governments National Poverty Eradication Programme (NAPEP) and National Economic Empowerment and Development Strategy (NEEDS), to mention a few, aimed at achieving the United Nation's Millennium Development Goals (MDGs) by 2015 required these microfinance institutions for success. The success of these programmes and projects for advancement of the MDGs are linked with the promotion of entrepreneurs in rural areas and subsequent reduction in the level of poverty (Ketu, 2008).

Other roles played by microfinance banks include; reorientation of the rural populace on sound financial practices, as well as issues such as reproductive health care, and girl child education. All these areas have direct link with entrepreneurial capabilities of the rural people.

\subsection{Challenges Facing Microfinance Banks}

i. High Operating Cost: Small units of services, pose the challenges of high operating cost, several loan applications to be processed, numerous accounts to be managed and monitored, and repayment collections to be made from several locations especially in rural communities.

ii. Repayment Problem: Loan default is a major threat to microfinance banks' sustainability; it is the deadly 'virus' which afflicts the operation of the banks. It demoralizes staff and deprives beneficiaries of further valuable services. iii. Inadequate Experienced Credit Staff: Micro financing is more than dispensing loans. To be viable, microfinance banks require experienced and skilled personnel. As a young and growing industry, there is a dearth of experienced staff in planning, product development and effective engagement with clients.

iv. Problems of illiteracy: This affects record keeping and decision-making ability of borrowers and consequently affects their relationship with the banks.

v. Inadequate or non-monitoring of micro and small enterprises by banks, leading to defaults.

\section{Data and Methodology}

The sample of respondents and data gathering procedure and methodology are discussed below. The sample data consists of all those that are directly or indirectly involved in the operations and management of small and medium scale entrepreneurial activities in the Ikeja Industrial area of Lagos. The sample consists of firms in manufacturing, microfinance, information technology, agro-allied industries, health care and support services.

$<$ Table 1 about here $>$

$<$ Table 2 about here $>$

The 57 small scale enterprises selected, were obtained from the Telephone Directory, while the 34 medium scale enterprises were taken from the 2008, Directory of the Manufacturers' Association of Nigeria (MAN). Most of the manufacturing firms in the sample are situated in industrial estates in Lagos - mainly Ikeja industrial estate, Ilupeju Industrial estate and Apapa-Iganmu Industrial estate.

There is an overall response rate of $78.7 \%$, with Information Technology firms recording the highest response rate of $81.8 \%$

\section{The Results and Analysis}

The responses of the interviewees regarding the role of micro-finance firms in poverty reduction and development of entrepreneurship are presented in four sub-sections, each dealing sequentially with the following (i) general perception of micro-finance banks, (ii) credit related services (iii) role of micro-finance banks in alleviating poverty and promoting entrepreneurship (iv) problems of microfinance banks.

\subsection{General Perception of Micro-Finance Banks}

Good banks - customer relationship is essential and a useful guide to bank performance. Thus the questionnaire focuses on the perception of the micro-finance banks by their customers (ie users of their services).

Q. What factors do you consider in the choice of bank to patronize?

Five factors were identified to finance customers choice of micro-finance banks. 
$<$ Table 3 about here $>$

Majority of respondents (90\%) preferred convenient location as the principal influencing factor. Parent company / friend influence was considered important by $88 \%$ of the respondents. It must be noted that some micro finance banks are subsidiaries of major Deposit Money Banking institutions. Such DMB subsidiary micro-finance banks attract higher patronage as they are considered to be more stable. Availability of credit and efficient operating services are other factors mentioned by the responding firms.

\subsection{Credit Related Services}

Availability of credit and required amount and tenor are of utmost importance to the survival of small and medium scale enterprises. Two sets of questions were posed as follows connection to micro-finance banks, as they currently operate, satisfy the credit needs of business firms, or there are some room for improvement.

(ii) In what ways are the lending facilities of micro-finance banks, different from those of regular Deposit Money Banks.

$<$ Table 4 about here $>$

Most of the responding firms ( $75 \%$ consider the services they get from micro-finance banks, satisfactory but with some reservations. They feel the service delivery of these institutions could be improved upon. As many as 65 of the respondents feel the services of micro-finance companies are very satisfactory, judging from their ugly experiences with commercial/deposit money banks. One-half (50\%) of the respondents consider the micro-finance services unsatisfactory. The more areas of services commodity considered as unsatisfactory is lending - ie loans and overdrafts particularly, credit policies - in terms of the amount of loan facility available to a customer and the short-tenor of such facilities. One quarter $(25 \%)$ of the respondents have no specific opinion on this issue.

Considering lending policies / facilities of micro-finance banks, do they differ from those of commercial banks as perceived by responding executives of SMEs.

In what ways do the lending policies of micro-finance banks different from those of regular Deposit Money Banks (Commercial banks)

$<$ Table 5 about here $>$

In a number of respects - easy access to credit, duration of credit facility commensurate with the needs of the client, cost of loan (ie interest rate and administrative charges), less insistence on collateral/security required for loan, shorter execution time for loan packaging as well as requirements for counterpart funding and compensatory balance, micro-finance banks dominate Commercial / Deposit Money banks.

\subsection{Role of Micro-Finance Banks in Alleviating Poverty}

The perception that micro-finance banks promote entrepreneurship and thereby help to reduce poverty was put to the test in the next question.

Q. How do micro-finance banks encourage entrepreneurship and / or reduce poverty

A number of respondents raised a variety of interventions by micro-finance banks as reflected in table 6 .

$<$ Table 6 about here $>$

All the respondents affirm that compared to Deposit Money Banks (Commercial Banks), Micro-finance banks are in a better position to encourage entrepreneurship and/or eradicate poverty through the provision of easy access to credit, a variety of services provision and delivery, provision of relevant investment advice and their proximity and ease of access to their client firms.

If micro-finance firms are so important in the development of entrepreneurship/small medium scale enterprises and by implication the overall economy, why are they not offering their services to the relevant sectors of the economy as required. This leads us to evaluating the problems of micro-finance banks, that inhibit their operations.

Q. What are the problems facing micro-finance firms that inhibit their operational performance.

The following factors were highlighted by respondents in order to significance.

$<$ Table 7 about here $>$

An overwhelming proportion of the responding firms (90\%) identified capital adequacy as the major constant of Micro-finance banks. Other constraints listed include - unfavourable policy environment (75\%), inability to attract quality personnel $(65 \%)$ and lack of appropriate modern technology $(60 \%)$ which can be a fall-out of inadequacy of capital. 
The usual problems of corruption, regulatory inhibitions and loan default were frequently mentioned by many of the respondents.

\section{Conclusion and Recommendation}

The CBN recognized micro finance as an important tool for poverty alleviation through empowering the micro and small entrepreneurs. The CBN wanted to see sustainable financial services available to those who don't have access to formal financial resources. Microfinance institutions are important in achieving this objective and are being promoted to be commercially viable through an appropriate policy and regulatory framework. From this, guidelines have been developed for microfinance institutions and other micro finance service providers. It is also important for the microfinance sector to gain both public and donor confidence.

Microfinance banks have played a great role especially in developing entrepreneurs in rural areas, they are however facing problems of high operating cost. It is recommended that the banks should encourage the formation of cooperatives so that a number of beneficiaries that are engaged in the similar business can collectively enjoy their services and hence a reduction in operating cost as well as a reduction in the likelihood for borrowers to default.

There is also the need to establish more microfinance banks especially in rural areas so as to further promote and develop the entrepreneurial capacity that is needed for transforming the areas and accelerating economic growth.

\section{References}

Central Bank of Nigeria. (2008). Guidelines and Procedures for the establishment of Microfinance Banks in Nigeria Published by the CBN.

Ketu, A. A. (20008) Microfinance Banks in Nigeria: An Engine for Rural Transformation West African Institute for Financial and Economic Management. Lagos Nigeria.

Muktar, M. (2009). The Role of Microfinance in the Promotion of Entrepreneurship in Semi Urban and Rural Area.

National Bureau of Statistics. (2005). Social Statistics in Nigeria Published by NBS.

Okigbo, P. N. C. (1981). The Nigerian Financial System. Longman, Harlow Essex, UK

Olaitan, M. A. (2006). Finance for Small and Medium Scale Enterprises in Nigeria Journal of International Farm Management. Vol. 3 No. 2 January.

Olajide, O. A. (1980). Financing Enterprises in Nigeria Through Cooperative Nigerian Institute of Social and Economic Research (NISER), Ibadan.

Smith, A. (1776). An inquiry into the nature and causes of the wealth of Nations. London, Methuen and Co Ltd.

Umar, S. H. (2008). The Experience of Microfinance Banks Operation in their Operational Location, Paper Presented at Sensitization Workshop on Microfinance Banking in Kano State.

Table 1. Present the overall distribution of the respondent organizations.

\begin{tabular}{|c|c|c|c|}
\hline Industry/Service & Small \% Response & Medium \% Rep & Total \% Rep \\
\hline Manufacturing & 14 & 9 & 23 \\
\hline Microfinance & 3 & 5 & 10 \\
\hline Information Technology & 6 & 5 & 11 \\
\hline Agro-Allied & 16 & 4 & 20 \\
\hline Health Care & 4 & 4 & 8 \\
\hline Support Services & 8 & 5 & 13 \\
\hline TOTAL & 51 & 34 & 85 \\
\hline
\end{tabular}


Table 2 .

\begin{tabular}{|c|c|c|c|c|c|c|}
\hline Response Rate & Manufacturing & Microfinance & I /T & Agro & H/C & Sup/Ser \\
\hline No in Sample & 23 & 10 & 11 & 20 & 8 & 13 \\
\hline No Responding & 18 & 8 & 9 & 16 & 6 & 10 \\
\hline Response (\%) & 78.3 & 80.0 & 81.8 & 80.0 & 75.0 & 76.9 \\
\hline
\end{tabular}

Table 3 .

\begin{tabular}{|c|c|}
\hline Factors & Responses (\%) \\
\hline Convenience of Location & 95 \\
\hline Parent Company/Friends influence & 88 \\
\hline Knowledge of the Chief/Executive / Principal Officers & 76 \\
\hline Availability of Credit & 80 \\
\hline Operating Services & 75 \\
\hline
\end{tabular}

Table 4. General Satisfaction with Credit-Related Services

\begin{tabular}{|c|c|}
\hline Factors & Response Percentage (\%) \\
\hline Very satisfactory & 65 \\
Satisfactory with reservations & 75 \\
Not satisfactory & 50 \\
Neither satisfactory nor unsatisfactory & 25 \\
\hline
\end{tabular}

Table 5. Perception of Differences in Lending Policies/Facilities of Micro-finance Banks Compared to Deposit Money Banks

\begin{tabular}{|c|c|}
\hline Factors & Percentage Response \\
\hline Access to Credit & 85 \\
Duration of Credit & 75 \\
Cost of Loan (Interest rate/ other charges & 90 \\
Collateral / Security required & 88 \\
Loan Packaging Time & 90 \\
Counterpart Fund/Compensatory Balance & 95 \\
\hline
\end{tabular}

Table 6. The Role of Micro-finance banks in Promoting Entrepreneurship and Eradicating Poverty

\begin{tabular}{|c|c|}
\hline Factors & Percentage Response \\
\hline Provision of cheap credit & 85 \\
Varieties of services offered & 75 \\
Advice Provided & 80 \\
Proximity to Customers & 90 \\
\hline
\end{tabular}


Table 7. Problems inhibiting the Operations of Micro-finance Banks

\begin{tabular}{|c|c|}
\hline Factors & Percentage Response \\
\hline Inadequate Capital & 90 \\
Unfavourable Policy Environment & 75 \\
Inability of attract Quality Personnel & 65 \\
Lack of appropriate technology & 60 \\
\hline
\end{tabular}

